\title{
Anti-Inflammatory Activities of Euglena gracilis Extracts
}

\author{
Paola Brun ${ }^{1, *(\mathbb{D}, \text { Anna Piovan }}{ }^{2}$, Rosy Caniato ${ }^{2}$, Vanessa Dalla Costa ${ }^{2}$, Anthony Pauletto ${ }^{1}$ and Raffaella Filippini ${ }^{2}$ \\ 1 Department of Molecular Medicine, Section of Microbiology, University of Padova, Via A. Gabelli 63, \\ 35127 Padova, Italy; anthony.pauletto@studenti.unipd.it \\ 2 Department of Pharmaceutical and Pharmacological Sciences, University of Padova, Via F. Marzolo 5, \\ 35131 Padova, Italy; anna.piovan@unipd.it (A.P.); rosy.caniato@unipd.it (R.C.); \\ vanessa.dallacosta@studenti.unipd.it (V.D.C.); raffaella.filippini@unipd.it (R.F.) \\ * Correspondence: paola.brun.1@unipd.it; Tel.: +39-049-8272-343
}

Citation: Brun, P.; Piovan, A.; Caniato, R.; Dalla Costa, V.; Pauletto, A.; Filippini, R. Anti-Inflammatory Activities of Euglena gracilis Extracts. Microorganisms 2021, 9, 2058. https://doi.org/10.3390/ microorganisms 9102058

Academic Editor: Nico Jehmlich

Received: 19 August 2021

Accepted: 24 September 2021

Published: 29 September 2021

Publisher's Note: MDPI stays neutral with regard to jurisdictional claims in published maps and institutional affiliations.

Copyright: (c) 2021 by the authors. Licensee MDPI, Basel, Switzerland. This article is an open access article distributed under the terms and conditions of the Creative Commons Attribution (CC BY) license (https:// creativecommons.org/licenses/by/ $4.0 /)$.

\begin{abstract}
Dietary supplementation with nutrients able to control intestinal and systemic inflammation is of marketable interest. Indeed, gastrointestinal homeostasis plays a significant role in maintaining human health. In this setting, E. gracilis may sustain or promote human health, but the effects on the intestinal inflammatory milieu are not clear. In this study, we investigated the anti-inflammatory activity of E. gracilis and inferred possible mechanisms. Paramylon, crude, and fractionated extracts were obtained from E. gracilis grown in vitro. Phytoconstituents of the extracts were characterized using TLC and HPLC UV-Vis. The anti-inflammatory and antioxidant activities were investigated in primary human macrophages and an intestinal epithelial cell line (HT-29). The analysis of the extracts led to identifying $\beta$-carotene, neoxanthin, diadinoxanthin, canthaxanthin, and breakdown products such as pheophytins and pheophorbides. E. gracilis fractionated extracts reduced the production of tumor necrosis factor- $\alpha$ triggered by bacterial lipopolysaccharide (LPS) in the short and long terms. Pheophytin $a$ and $b$ and canthaxanthin increased the intracellular reducing potential and dampened the production of LPS-induced reactive oxygen species and lipid peroxidation, intracellular events usually involved in the perpetuation of chronic inflammatory disorders. This study rationalizes the role of specific extract fractions of E. gracilis in controlling LPS-driven intestinal inflammation.
\end{abstract}

Keywords: microalgae; lipopolysaccharide; inflammation; reactive oxygen species; novel food

\section{Introduction}

Microalgae are industrially valuable microorganisms with great metabolic potential. Indeed, microscopic algae biosynthesize, metabolize, accumulate, and secrete proteins, fatty acids, polysaccharides, carotenoids, phycobilins, vitamins, and sterols more efficiently than traditional crops. In recent years, primary and secondary metabolites from microalgae have been used in the food, pharmaceutical, and cosmetic industries [1], where microalgae have competitive advantages over other plant sources since they grow in soilless medium without seasonal limitations. In this context, the European Union encourages the Bioeconomy, a strategy where algae represent promising biological resources with potential applications in different fields [2]. Indeed, microalgae-based high-value molecules (such as xanthophylls and $\beta$-carotene) have considerable market potential, and the development of novel foods based on microalgal biomass is an exciting tool providing nutritional supplements with biologically active compounds. Therefore, the industrial cultivation of microalgae has increased dramatically over the last few decades [3].

Euglena gracilis Klebs (Euglenozoa, Euglenophyceae) is a freshwater flagellated unicellular microalga representing one of the simplest and earliest derived eukaryotic cells. It grows under heterotrophic, photoautotrophic, or photoheterotrophic conditions in anaerobically or aerobically mode [1]. Moreover, like most other microalgae, E. gracilis contains several bioactive compounds that make it a new functional food, meeting the requirements 
for tackling malnutrition in developing countries and sustaining human health. Indeed, on 4 May 2020, the EFSA Panel on Nutrition, Novel Foods and Food Allergens (NDA) approved the Euglena gracilis dried whole cells as a novel food [4].

In addition to fatty acids, carotenoids, and proteins [5], E. gracilis is a good source of paramylon, a linear $\beta-(1,3)$ glucan polysaccharide with high molecular weight $[6,7]$ considered a functional dietary fiber for health purposes. Numerous studies have evaluated the effects of E. gracilis on human health, but only a few reports have addressed the biological activity of paramylon or specific E. gracilis extracts [8-15]. Oral administration of E. gracilis improved the glycemic control in a rat model of type 2 diabetes mellitus, whereas the aqueous extract from the microalga inhibited lipid accumulation in cultured human adipose-derived stem cells $[14,16]$. According to recent experimental studies, paramylon modulates the immune system response by reducing the production of proinflammatory cytokines and disease evidence in an animal model of arthritis [17] and atopic dermatitis [18]. Moreover, paramylon was supposed to inhibit gene expression of peroxisome proliferator-activated receptor- $\gamma$, a transcription factor emerging as the checkpoint for setting the inflammatory milieu during obesity $[16,19]$.

Because of the anti-inflammatory effect, supplementation with E. gracilis is a promising approach for treating overweight and obesity - metabolic disorders characterized by increasing prevalence in the youth population [20]. Indeed, it is well accepted that low-grade systemic inflammation is strictly associated with the onset of obesity and obesity-related diseases such as atherosclerosis, cardiovascular risk, hepatic steatosis, and diabetes [21]. During metabolic disorders, inflammation disrupts intestinal tight junctions and leads to a leaky gut barrier, allowing increased circulating levels of intestinal bacteria-derived lipopolysaccharide (LPS) [22]. The resulting metabolic endotoxemia amplifies inflammation at local and systemic compartments, and it recruits activated macrophages in the gut wall, visceral fat, liver, and joints [23]. However, the increased circulating levels of LPS are not such a rare event, even in lean and healthy subjects. Chylomicrons are preferential shuttles of LPS, and the occasional intake of fatty meals allows the passage of intestinal LPS into circulation. Impaired lipoprotein metabolism reduces LPS catabolism and increases time-limited endotoxemia episodes, eventually leading to inflammatory-related disorders $[23,24]$. During inflammation, cells generate high levels of reactive oxygen species (ROS) central to endothelial dysfunction and tissue injury, thus accelerating the progression of obesity, atherosclerosis, and type 2 diabetes [25]. However, ROS are normal metabolic byproducts involved in modulating cellular functions such as, paradoxically, signaling pathways enhancing insulin sensitivity in response to physiological stimuli [26]. In eukaryotic cells usually endowed with antioxidant mechanisms and free radical scavengers, the reducing potential sets the hormetic phenomenon of the ROS, defined by beneficial effects at low doses and detrimental effects at higher concentrations.

Considering the requirement of novel functional food characterized by high metabolic potential, in this study we investigated the anti-inflammatory effects of paramylon and crude and fractionated extracts of E. gracilis. We did not collect evidence for the antiinflammatory effects of paramylon. On the contrary, we revealed that in cultured human primary macrophages and intestinal epithelial cell line, specific fractionated extracts of E. gracilis increased the cellular threshold for ROS activation under normal conditions, leading to reduced oxidative burst and pro-inflammatory activation triggered by LPS.

\section{Materials and Methods}

\subsection{Cultures of Euglena gracilis}

E. gracilis strain (1224-5/27) was obtained from the Culture Collection of Algae (SAG; Göttingen, Germany). Cells were cultured in CM liquid medium [27] supplemented with sodium acetate $3 \mathrm{~g} / \mathrm{L}$, in non-agitated Erlenmeyer flasks. The $\mathrm{pH}$ was adjusted to 6.8. The cultures were maintained at $24-26{ }^{\circ} \mathrm{C}$ under a photoperiod (16/8 h light-dark cycle). A growth curve was calculated by determining the fresh weight every second or third day over a cultivation period of 14 days. The experiment was repeated three times. As soon 
as the cultures reached the stationary growth phase, an inoculum was transferred in a fresh medium, whereas the remaining algal cells were harvested by centrifugation and concentrated to a biomass slurry that was washed twice with deionized water. Finally, the cleaned samples were stored at $-20^{\circ} \mathrm{C}$ until use.

\subsection{Preparation of Paramylon and Crude and Fractionated Extracts from Euglena gracilis Cells}

To obtain paramylon $(\mathrm{P})$, cells were extracted three times with acetone in an ultrasound bath for $20 \mathrm{~min}$ at room temperature. After centrifugation, the pellet was washed repeatedly with deionized water containing $10 \%$ sodium dodecyl sulfate in a water bath at $100{ }^{\circ} \mathrm{C}$. The solid residue, paramylon, was washed with ethanol to eliminate water and was freezedried [28]. To obtain the crude extract (CE), cells were extracted three times with acetone in an ultrasound bath for $20 \mathrm{~min}$ at room temperature. After centrifugation, the combined acetone extracts were evaporated to dryness. The fractionated extract (FE) was obtained from CE-an aliquot of CE was suspended in methanol/water (40:60) and extracted by ethyl acetate. The ethyl acetate phase was separated and evaporated to dryness. FE was fractionated by analytical TLC, using silica gel 60 F254 pre-coated plates (Merck, Milan, Italy) and acetone/n-hexane (4:6) as eluent to obtain sub-fractionated extracts (sFE1-8).

The analysis of the extracts was performed using an Agilent 1100 HPLC Series System (Agilent, Santa Clara, CA, USA) equipped with degasser, quaternary gradient pump, column thermostat, and UV-Vis detector. A Gemini $5 \mu \mathrm{m}$ C6-Phenyl column $(250 \times 4.6 \mathrm{~mm})$ from Phenomenex (Torrance, CA, USA) was set at $40{ }^{\circ} \mathrm{C}$. Analyses were conducted in the isocratic mode, using acetonitrile/methanol $(10: 90 ; v / v)$ at a flow rate of $1 \mathrm{~mL} \mathrm{~min}^{-1}$, with an injection volume of $10 \mu \mathrm{L}$; detection was performed at 280, 365, 438, and $460 \mathrm{~nm}$. Spectra were acquired from 200 to $800 \mathrm{~nm}$. The identification of the compounds was performed by comparing TLC and HPLC chromatograms and UV-Vis spectra using the available reference standards (zeaxanthin, canthaxanthin, $\beta$-carotene: Sigma-Aldrich, Milan, Italy) and data obtained from published references [29-34]. Chlorophyll a and chlorophyll b content was determined as described by Yang et al. [30]. Pheophytin content was measured according to the method of Lichtenthaler [29], as reported by Yang et al. [30]. One aliquot of the extract was solubilized with acetone/water (4:1) and, after appropriate dilution, the maximum absorbance was read at $663 \mathrm{~nm}, 646 \mathrm{~nm}, 665 \mathrm{~nm}$, and $653 \mathrm{~nm}$ for chlorophyll a, chlorophyll b, pheophytin $a$, and pheophytin $b$, respectively. The content of pigments was calculated using the following equations:

$$
\begin{aligned}
& \text { Chlorophyll a }(\mu \mathrm{g} / \mathrm{mL})=12.25 \text { A663 }-2.55 \text { A646 } \\
& \text { Chlorophyll b }(\mu \mathrm{g} / \mathrm{mL})=20.31 \text { A646 }-4.91 \text { A663 } \\
& \text { Pheophytin a }(\mu \mathrm{g} / \mathrm{mL})=22.42 \text { A665 }-6.81 \text { A653 } \\
& \text { Pheophytin b }(\mu \mathrm{g} / \mathrm{mL})=40.17 \text { A653 }-18.58 \text { A665 }
\end{aligned}
$$

Since standards were not available for all carotenoids, zeaxanthin and $\beta$-carotene were selected as external standards for the quantification. Stock solutions $(1 \mathrm{mg} / \mathrm{mL})$ were prepared in acetonitrile/methanol $(10: 90 ; v / v)$, and the calibration curves were obtained in a concentration range, respectively, of $0.25-25 \mu \mathrm{g} / \mathrm{mL}\left(R^{2}=0.9999\right), 1-100 \mu \mathrm{g} / \mathrm{mL}\left(R^{2}=0.9996\right)$, with six concentration levels. Calibration curves were constructed by plotting the peak area at $438 \mathrm{~nm}$ vs. the pigment concentrations. Xanthophylls were quantified as zeaxanthin equivalents. The amount of the compounds was expressed as $\mathrm{mg} / \mathrm{g}$ of the dry weight of the extract.

For in vitro biological experiments, $\mathrm{CE}$ and FE were dissolved in DMSO at $1 \mathrm{mg} / \mathrm{mL}$; $\mathrm{P}$ was dissolved at $1 \mathrm{mg} / \mathrm{mL}$ in $50 \mathrm{mM}$ Tris $\mathrm{HCl} \mathrm{pH} \mathrm{7.5,} 1 \mathrm{M}$ sucrose, $25 \mathrm{mM} \mathrm{NaF}$, and $3 \mathrm{mg} / \mathrm{mL}$ CHAPS prepared in pyrogen-free water. Endotoxins levels were assessed in all extracts using LAL Chromogenic Endotoxin Quantitation Kit (Pierce; Thermo Fisher Scientific, Monza, Italy) and following the vendor instructions. Working solutions were prepared in cell culture media. 


\subsection{Human Cell Culture Conditions}

Primary human monocytes were isolated from buffy-coat preparations of whole blood obtained from the blood bank of the Padova University Hospital. The study protocol was reviewed and approved by the hospital's ethics committee of the Padova University Hospital (registration number CE: 091/2016). The buffy-coat was mixed 1:1 (vol/vol) with sterile RPMI 1640 Medium (Gibco; Life Technologies, Monza, Italy) and layered over FicollPaque PLUS (GE Healthcare; Sigma, Milan, Italy). Samples were centrifuged (1200 rpm, $30 \mathrm{~min}$ ), and peripheral blood mononuclear cells (PBMCs) were collected. Cells were washed (1600 rpm, $10 \mathrm{~min}$ ), suspended in RPMI 1640, supplemented with $1 \%$ penicillinstreptomycin and $10 \%$ heat-inactivated fetal bovine serum (FBS; Life Technologies), and counted. PBMCs were seeded $\left(3 \times 10^{5}\right.$ cells/well) in 96-well tissue-culture plates (Corning; Sigma; Milan; Italy) and cultured for $3 \mathrm{~h}$ in a $5 \% \mathrm{CO}_{2}$, humidified, $37{ }^{\circ} \mathrm{C}$ incubator. Floating cells were then removed, whereas attached cells were washed and differentiated in mature macrophages by incubation for 10 days with complete medium supplemented with recombinant human granulocyte-macrophage colony-stimulating factor (rhGM-CSF, $2 \mathrm{ng} / \mathrm{mL}$; ImmunoTools; Friesoythe, Germany). The culture medium was renewed every 3 days.

HT-29 human intestinal epithelial cell line was purchased from ATCC (LGC Standards; Milan, Italy) and cultured in Dulbecco's modified Eagle medium (DMEM) containing 1\% penicillin-streptomycin and 10\% of FBS (all provided by Life Technologies). HT-29 were seeded at $2 \times 10^{4}$ cells/well in 96-well tissue culture plates or at $2 \times 10^{5}$ cells/well in 24-well tissue-culture plates (Corning).

\subsection{Cell Viability Assay}

Differentiated primary macrophages or HT-29 were incubated for $24 \mathrm{~h}$ with E. gracilis extracts at final concentrations ranging from 0 to $100 \mu \mathrm{g} / \mathrm{mL}$. Control cells were incubated with respective vehicles (see Section 2.2) at the highest final volumes used. At the end of incubation, MTT solution ( $50 \mu \mathrm{g} / 100 \mu \mathrm{L}$; Sigma) was added, and cells were incubated for $4 \mathrm{~h}$ at $37^{\circ} \mathrm{C}$. Formazan crystals were then solubilized in $100 \mu \mathrm{L}$ of SDS $10 \% \mathrm{w} / \mathrm{vol}$, $\mathrm{HCl} 0.01 \mathrm{~N}$. The absorbance was recorded $16 \mathrm{~h}$ later at $590 \mathrm{~nm}$ using a microplate reader (Sunrise; Tecan, Männedorf (Zürich); Switzerland). $\mathrm{IC}_{50}$ values were determined in three separate experiments, each one performed in duplicate.

\subsection{Enzyme-Linked Immunosorbent Assay}

Differentiated primary human macrophages were incubated for $24 \mathrm{~h}$ with $E$. gracilis extracts at final concentrations ranging $0-10 \mu \mathrm{g} / \mathrm{mL}$ with or without $100 \mathrm{ng} / \mathrm{mL}$ lipopolysaccharide (LPS from Salmonella enterica serotype Typhimurium; Sigma). In different experiments, macrophages were pretreated for 3 days with $0-10 \mu \mathrm{g} / \mathrm{mL}$ of E. gracilis extracts. As a positive control, cells were incubated with dexamethasone $(1 \mu \mathrm{g} / \mathrm{mL} ;$ Sigma). Stimuli were renewed every day, and cells were finally challenged with LPS for $24 \mathrm{~h}$. At the end of incubation, conditioned media were collected and stored at $-80^{\circ} \mathrm{C}$. Levels of tumor necrosis factor (TNF)- $\alpha$ were measured in the conditioned media using commercially available enzyme-linked immunosorbent assay kits (ELISA, Affymetrix eBioscience; Prodotti Gianni, Milan, Italy) and developed using 3,3',5,5' -tetramethylbenzidine (TMB). Optical densities were measured at $450 \mathrm{~nm}$ using a microplate reader (Sunrise). The sensitivity of the assay was $15 \mathrm{pg} / \mathrm{mL}$. Experiments were performed in triplicate.

\subsection{Assessment of Intracellular Glutathione Content}

Intracellular glutathione (GSH) levels were assessed in HT-29 cells using Ellman's method [35]. Cells were cultures in 24-well plates and treated for 4 days with $10 \mu \mathrm{g} / \mathrm{mL}$ of extracts obtained from E. gracilis. Stimuli were renewed every day. Cells were collected and incubated with $20 \% \mathrm{w} / \mathrm{vol}$ cold trichloroacetic acid for $30 \mathrm{~min}$. Samples were centrifuged (13,000 rpm for $5 \mathrm{~min}$ ) and added with 10\% vol/vol 5,5'-dithiobis-(2-nitrobenzoic acid) 
(DTNB). The absorbance was recorded at $412 \mathrm{~nm}$. Values were plotted on a standard curve obtained by serial dilution of $\mathrm{N}$-acetylcysteine (Sigma).

\subsection{Detection of Intracellular Reactive Oxygen Species (ROS) Levels}

HT-29 seeded in 24-well plates were pretreated with $10 \mu \mathrm{g} / \mathrm{mL}$ of extracts from E. gracilis for 3 days. Stimuli were renewed every day. When described, cells were incubated with LPS $100 \mathrm{ng} / \mathrm{mL}$ for $24 \mathrm{~h}$. Cells were loaded for $30 \mathrm{~min}$ at $37^{\circ} \mathrm{C}$ with $10 \mu \mathrm{M} 2^{\prime}, 7^{\prime}$ dichlorodihydrofluorescein diacetate $\left(\mathrm{H}_{2} \mathrm{DCFDA}\right.$; Molecular Probes, Invitrogen, Italy) in warm PBS [36]. Cells were washed twice, harvested by Trypsin-EDTA, washed, and analyzed using BD FACSCalibur flow cytometer (Becton Dickinson, Franklin Lakes, NJ, USA). Ten thousand events were acquired for each experimental condition. Results were analyzed using the WinMDI 2.9 program (Windows Multiple Document Interface for Flow Cytometry).

\subsection{Evaluation of Lipid Peroxidation}

Lipid peroxidation was determined by measuring the thiobarbituric acid (TBA, Inalco, Italy) reactive substances (TBA reactants). HT-29 seeded in 24-well plates was pretreated with $10 \mu \mathrm{g} / \mathrm{mL}$ of E. gracilis extracts and then challenged with $100 \mathrm{ng} / \mathrm{mL}$ LPS, as described above. Cells were then added with $20 \% \mathrm{w} / \mathrm{vol}$ cold trichloroacetic acid and centrifuged. Supernatants were incubated with $0.67 \%$ solution of TBA at $100{ }^{\circ} \mathrm{C}$ for $10 \mathrm{~min}$. The absorbance was recorded at $532 \mathrm{~nm}$. Values were plotted on a standard curve obtained by serial dilution of malonaldehyde tetrabutylammonium salt (Sigma). TBA reactant levels were calculated using a molar extinction coefficient of $1.56 \times 10^{5} \mathrm{M}^{-1} \times \mathrm{cm}^{-1}$ [36]. TBA reactant levels were normalized to protein concentration determined by bicinchoninic acid assay (Pierce; Thermo Fisher Scientific, Milan, Italy).

\subsection{Statistical Analysis}

Results are reported as mean \pm SE. Graphs were generated using GraphPad Prism 3.03 (San Diego, CA, USA). Statistical significance was calculated using one-way ANOVA test followed by the Newman-Keuls post hoc test. $p<0.05$ was considered statistically significant.

\section{Results}

\subsection{Analysis of Euglena gracilis Extracts and Biological Activities}

Depending on the solvents used and the protocols, the chemical profile and the biological activities of the extracts can vary greatly. Indeed, the fractionation process can produce more or less active fractions, and the purification process could remove inactive extracts, bringing out the active components. To investigate the most convenient extracting protocol for E. gracilis, in this study we evaluated three methods that were applied on E. gracilis cultured cells to yield the paramylon (P), the crude extract (CE), and the fractionated extract (FE). The CE fraction analysis led to identifying neoxanthin (1), diadinoxanthin (2), zeaxanthin (3), canthaxanthin (4), chlorophyll b (5), chlorophyll a (6), and $\beta$-carotene (7); unidentified xanthophylls were also detected. $\beta$-carotene and the same xanthophylls retrieved in CE were identified in FE. In addition, the analysis of FE reported chlorophyll breakdown products such as pheophytin b (8), pheophytin a (9), and pheophorbides (Table 1, Figure 1A,C).

Chlorophyll a, chlorophyll b, pheophytin a, pheophytin $\mathrm{b}$, and total carotenoids were determined in $\mathrm{CE}$ and FE fractions (Figure 1). The identified compounds are expressed as $\mathrm{mg} / \mathrm{g}$ of dry extract and the relative content of the carotenoids in CE and FE (Figure 1B,D). As reported in Figure 1B,D, diadinoxanthin represented about the $56 \%$ of total carotenoids in CE and FE fractions; $\beta$ carotene was also recovered in both fractions. CE fraction differed from the FE fraction for the higher content in neoxanthin. 
Table 1. Identification of compounds in CE and FE fractions. Retention time (Rt), absorption maxima, and TLC Retention factor (Rf) of the identified compounds.

\begin{tabular}{cccc}
\hline Compounds & Rt (min) & Absorption Maxima (nm) & Rf \\
\hline neoxanthin (1) & 3.3 & 435,465 & 0.6 \\
\hline diadinoxanthin (2) & 3.6 & $278,445,475$ & 0.5 \\
\hline zeaxanthin (3) & 3.7 & $275,450,476$ & 0.6 \\
\hline canthaxanthin (4) & 3.8 & 295,475 & 0.65 \\
\hline chlorophyll b (5) & 5.7 & 458,617 & 0.7 \\
\hline chlorophyll a (6) & 6.8 & 431,663 & 0.68 \\
\hline B-carotene (7) & 9.3 & $275,451,476$ & 1 \\
\hline pheophytin b (8) & 11.7 & 441,650 & 0.75 \\
\hline pheophytin a (9) & 13.1 & 410,665 & 0.85 \\
\hline pheophorbides & $3.6-3.8$ & 441,$650 ; 410,665$ & 0.2 \\
\hline
\end{tabular}

A

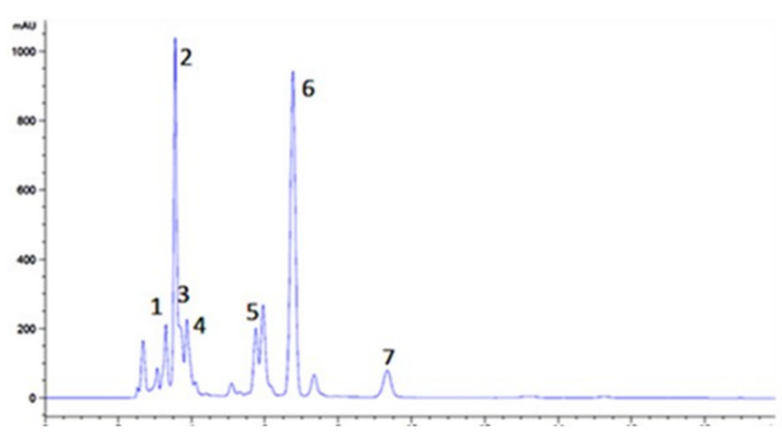

C

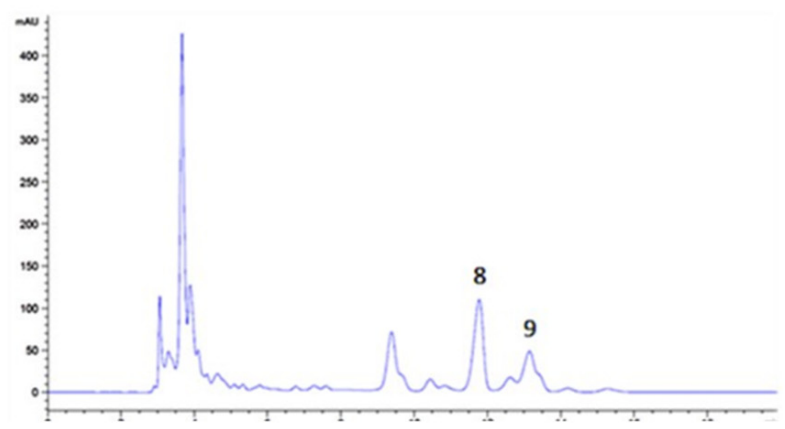

B

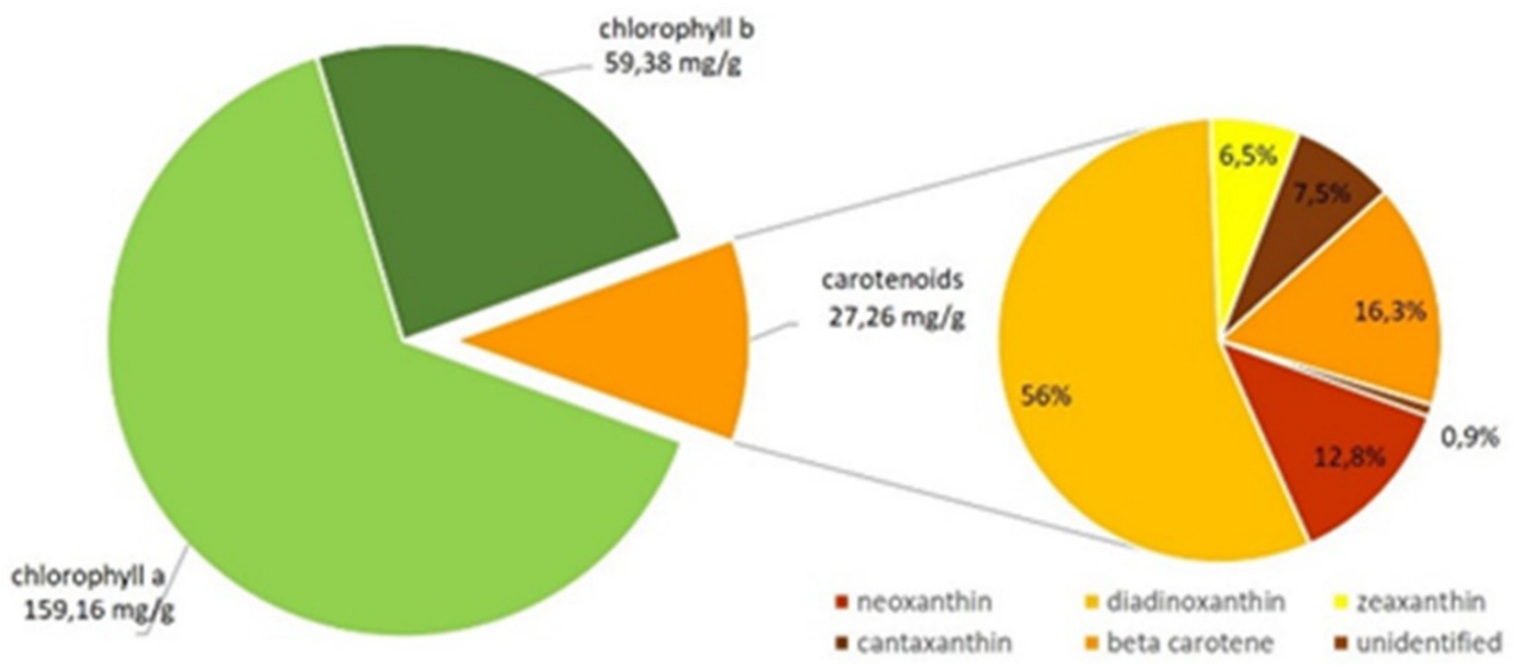

Figure 1. Cont. 


\section{D}

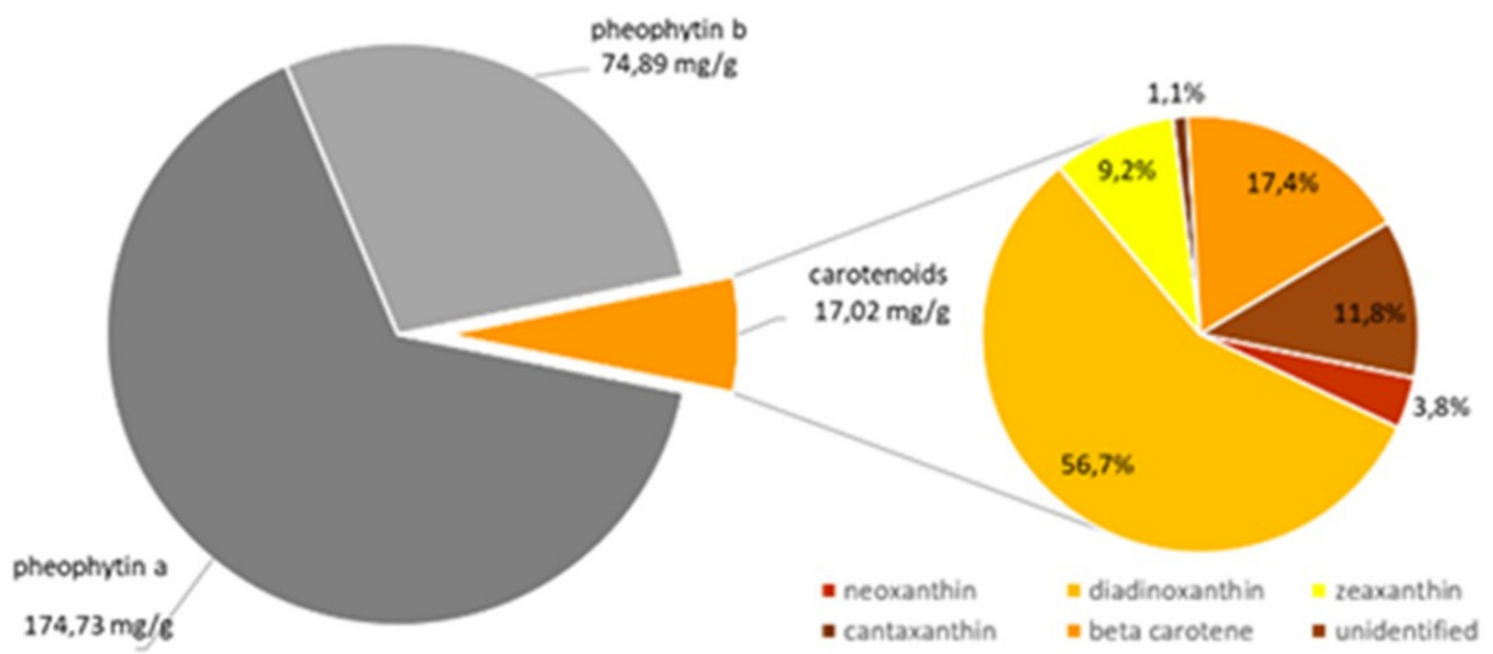

Figure 1. (A) Chromatogram of CE acquired at $438 \mathrm{~nm}$; (B) chlorophyll a, chlorophyll b, total carotenoids expressed as $\mathrm{mg} / \mathrm{g}$ of dry CE extract and relative carotenoid content. (C) Chromatogram of FE acquired at $438 \mathrm{~nm}$; (D) pheophytin a, pheophytin b, total carotenoids expressed as $\mathrm{mg} / \mathrm{g}$ of dry FE extract and relative carotenoid content.

Extracts $\mathrm{P}, \mathrm{CE}$, and FE were assessed for anti-inflammatory activity. As determined by ELISA, cultured human primary macrophages stimulated with LPS significantly increased the production of TNF- $\alpha(648.9 \pm 46.87 \mathrm{pg} / \mathrm{mL})$ as compared with unstimulated macrophages $(115.1 \pm 53.27 \mathrm{pg} / \mathrm{mL} ; p<0.01)$. The levels of TNF- $\alpha$ induced by LPS were significantly reduced only in macrophages incubated with FE, $10 \mu \mathrm{g} / \mathrm{mL}$ (Figure 2A). We did not observe any changes in TNF- $\alpha$ production in macrophages incubated with $\mathrm{P}$ and $\mathrm{CE}$ extracts. As reported in the literature, LPS triggers reactive oxygen species (ROS) involved in intracellular signals that eventually result in inflammatory cytokine production [37]. We, therefore, investigated whether extracts $\mathrm{P}, \mathrm{CE}$, and FE reduced the intracellular ROS levels ignited by LPS stimulation. As reported in Figure 2B, LPS significantly increased ROS levels in HT-29 cells loaded with $\mathrm{H}_{2}$ DCFDA, a fluorescent probe detecting intracellular ROS. FE significantly reduced intracellular ROS in cells stimulated with LPS, whereas P and $\mathrm{CE}$ were not effective.

Considering these results, FE was fractionated by TLC, obtaining the sub-fractionated extracts $(\mathrm{sFE}) 1 \div 8$. Figure 3 reports the chemical constituents of sFE. Chromatograms of sFE1 $\div$ sFE8 are reported in Supplementary Figure S1. 
A

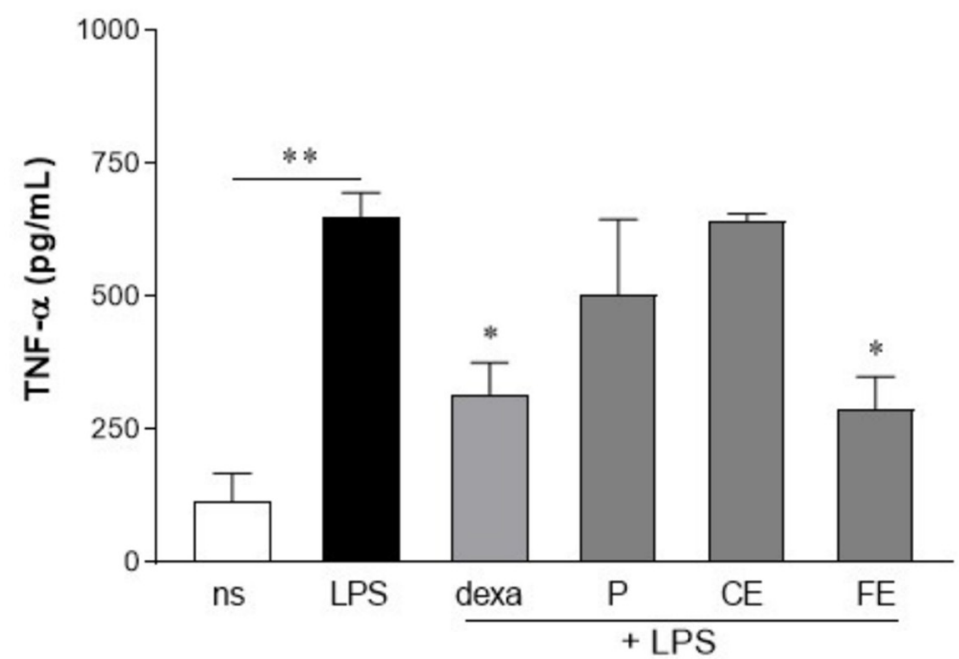

B

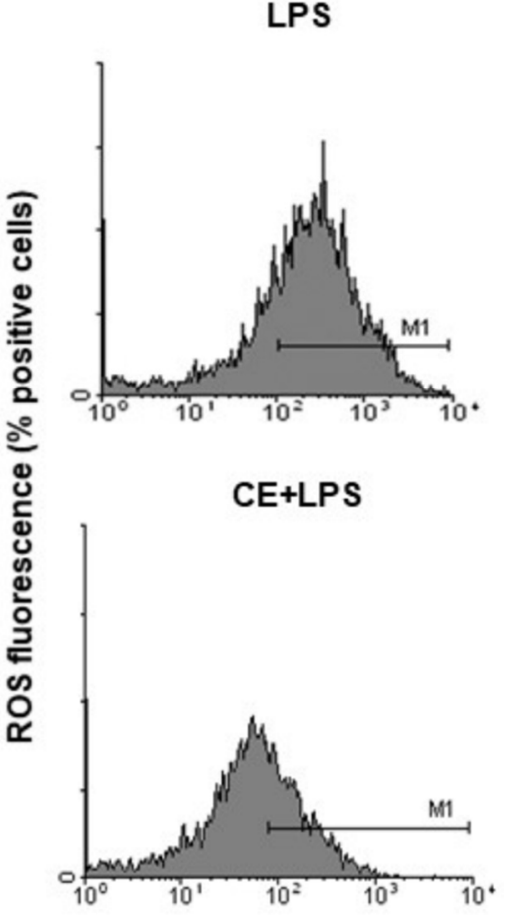

P+LPS

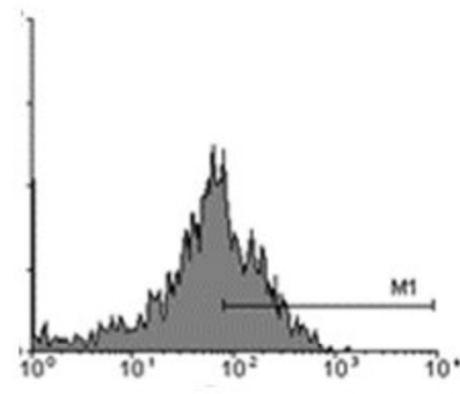

FE+LPS

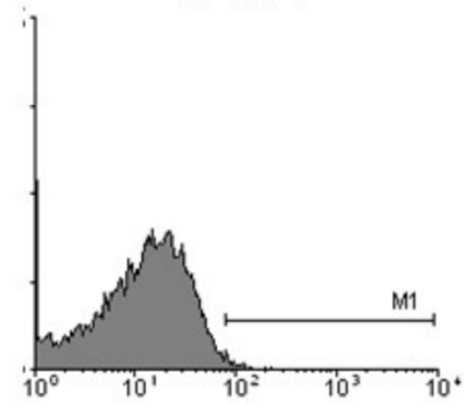

Figure 2. (A) Anti-inflammatory activity of extracts from E. gracilis. Primary human macrophages were stimulated for $24 \mathrm{~h}$ with $10 \mu \mathrm{g} / \mathrm{mL}$ of extracts obtained from E. gracilis and $100 \mathrm{ng} / \mathrm{mL}$ of lipopolysaccharide (LPS). TNF- $\alpha$ production was assessed in the conditioned media by ELISA. Data are reported as mean $\pm \mathrm{SE}$ of the results collected in three independent experiments, each performed in triplicate. Dexa: dexamethasone $1 \mu \mathrm{g} / \mathrm{mL}$. ${ }^{* *}$ denotes $p<0.01 \mathrm{vs.} \mathrm{non-stimulated} \mathrm{cells;}{ }^{*}$ denotes $p<0.05$ vs. cells stimulated with LPS. (B) HT-29 cells were loaded with H2DCFDA and treated with extracts from E. gracilis and LPS $(100 \mathrm{ng} / \mathrm{mL})$. Positive cells were analyzed by cytofluorimeter. Representative histograms are reported. 
sub-Fractionated Extract TLC

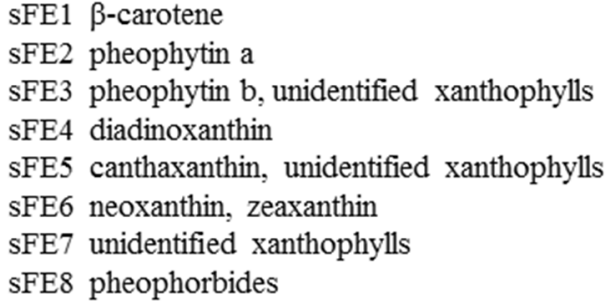

Figure 3. Schematic representation of the compounds identified in sub-fractionated extracts (sFE).

\subsection{Identification of Non-Cytotoxic Concentrations of Extracts from E. gracilis}

The cytotoxic activity of extracts obtained from E. gracilis was assessed on cultured human primary macrophages and HT-29 cells by the MTT assay. Extracts were tested at concentrations ranging from 0 to $100 \mu \mathrm{g} / \mathrm{mL}$, and the calculated $\mathrm{IC}_{50}$ values are listed in Table 2. $\mathrm{P}, \mathrm{CE}$, and FE reported $\mathrm{IC}_{50}$ values higher than $30 \mu \mathrm{g} / \mathrm{mL}$. Sub-fractionated extracts reported no reduction in cell viability at the highest concentration tested $(100 \mu \mathrm{g} / \mathrm{mL}$; Table 2). No cytotoxic activity was detected in cells incubated with the vehicles (data not shown). Considering these results, we decided to perform the subsequent experiments using extracts at concentrations $10 \mu \mathrm{g} / \mathrm{mL}$ or lower.

Table 2. Cell viability. Cell viability was determined in vitro using MTT test on differentiated primary human macrophages $(\mathrm{M} \varphi)$ or HT-29 cells incubated for $24 \mathrm{~h}$ with extracts obtained from E. gracilis. $\mathrm{IC}_{50}$ is expressed in $\mu \mathrm{g} / \mathrm{mL}$.

\begin{tabular}{ccc}
\hline $\begin{array}{c}\text { Extracts from } \\
\text { E. } \text { gracilis }\end{array}$ & $\begin{array}{c}\text { M } \boldsymbol{\varphi} \\
\text { IC50 }\end{array}$ & $\begin{array}{c}\text { HT-29 } \\
\text { IC50 }\end{array}$ \\
\hline P & 30 & 45 \\
CE & 48 & 57 \\
FE & 47 & 59 \\
sFE1 & $>100$ & $>100$ \\
sFE2 & 31 & 39 \\
sFE3 & 33 & 41 \\
sFE4 & 50 & 55 \\
sFE5 & 47 & 58 \\
sFE6 & 38 & 46 \\
sFE7 & 37 & 42 \\
sFE8 & 36 & 44 \\
\hline
\end{tabular}

\subsection{Sub-Fractionated Extracts from E. gracilis Dampen LPS-Induced Inflammation}

We determined by LAL test the endotoxin levels in E. gracilis extracts, sub-fractionated extracts, and vehicles, and we found that the levels of endotoxins were below $0.1 \mathrm{EU} / \mathrm{mL}$, corresponding to $0.01 \mathrm{ng} / \mathrm{mL}$ (data not shown). As reported by extracts, sub-fractionated extracts obtained from FE were tested for the anti-inflammatory activity in cultured human primary macrophages stimulated with LPS. As reported in Figure 4, all the sFE reduced the production of TNF- $\alpha$ but sFE6 and sFE7. For the sFE endowed with anti-inflammatory activity, the extent of TNF- $\alpha$ reduction was comparable to FE. 


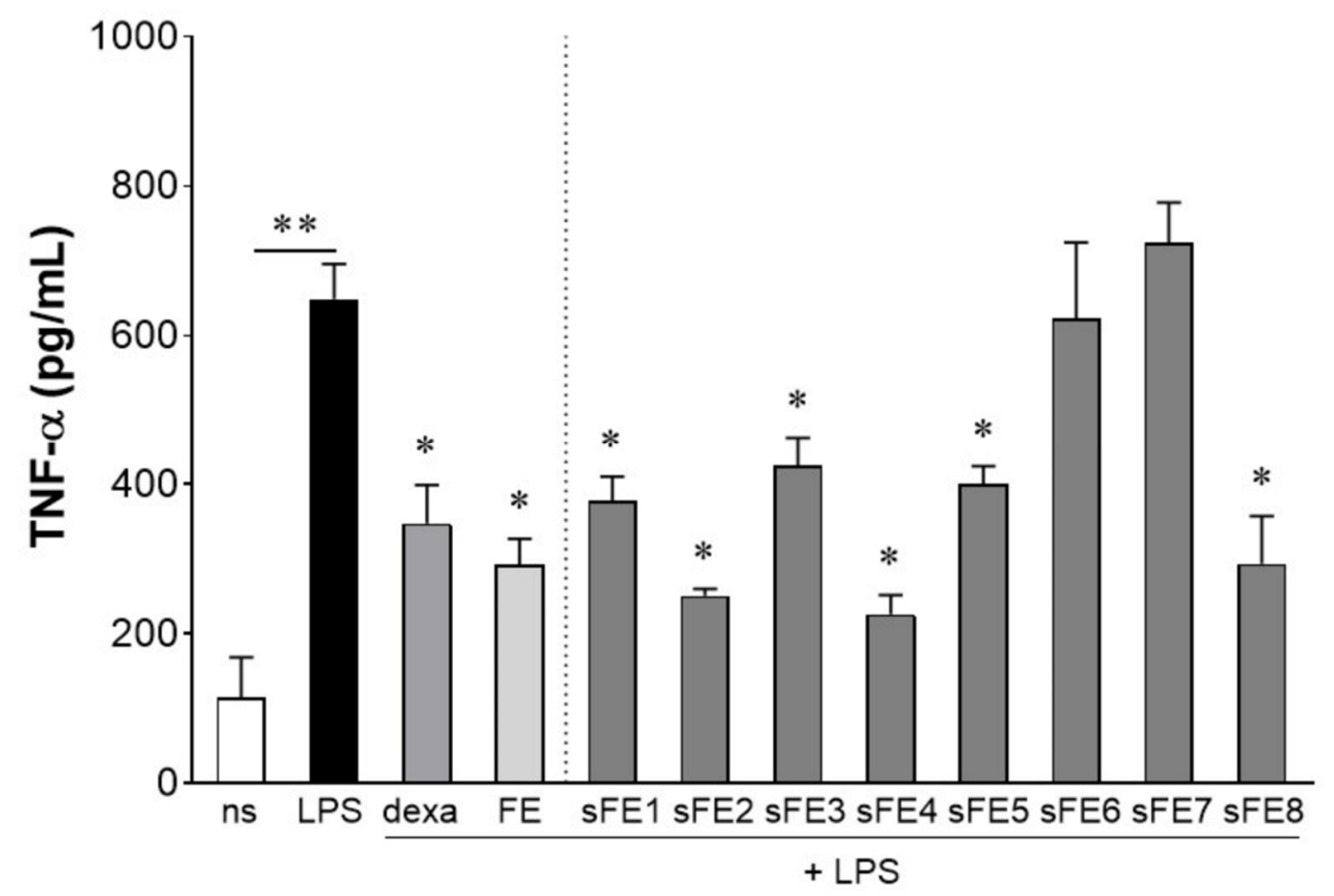

Figure 4. Anti-inflammatory activity of FE and sFE obtained from E. gracilis. Primary human macrophages were stimulated for $24 \mathrm{~h}$ with $10 \mu \mathrm{g} / \mathrm{mL}$ of extracts obtained from E. gracilis, $1 \mu \mathrm{g} / \mathrm{mL}$ dexamethasone (dexa), and $100 \mathrm{ng} / \mathrm{mL}$ of lipopolysaccharide (LPS). TNF- $\alpha$ production was assessed in the conditioned media by ELISA. Data are reported as mean \pm SE of the results collected in three independent experiments, each performed in triplicate. ${ }^{* *}$ denotes $p<0.01$ vs. non-stimulated cells; * denotes $p<0.05$ vs. cells stimulated with LPS.

In dose-response experiments, we revealed that different extracts from E. gracilis preserved the anti-inflammatory activity at concentrations lower than $10 \mu \mathrm{g} / \mathrm{mL}$. Results of dose-response experiments are reported in Table 3 as the lowest concentration of extracts that can reduce by $25 \%$ the production of TNF- $\alpha$ triggered by LPS. As noted, FE, sFE1, sFE2, sFE4, sFE5, and sFE8 significantly reduced production of TNF- $\alpha$ at concentrations lower than $10 \mu \mathrm{g} / \mathrm{mL}(p<0.05)$. sFE1 was the most effective, as the anti-inflammatory activity was evident at $0.1 \mu \mathrm{g} / \mathrm{mL}$ (Table $3,24 \mathrm{~h}$ ).

Table 3. Anti-inflammatory activity of extracts, dose-response assays. Human primary macrophages were stimulated with LPS $100 \mathrm{ng} / \mathrm{mL}$ and extracts $(0-10 \mu \mathrm{g} / \mathrm{mL})$ for $24 \mathrm{~h}$. In different experiments, cells were incubated with extracts $(0-10 \mu \mathrm{g} / \mathrm{mL})$ for 3 days. Stimuli were renewed every day, and cells were finally challenged with LPS (100 ng/mL) for $24 \mathrm{~h}$ (total experimental time: 4 days). TNF- $\alpha$ was measured in the conditioned media by ELISA. Data are reported as the lowest concentrations $(\mu \mathrm{g} / \mathrm{mL})$ of E. gracilis extracts that significantly $(p<0.05)$ reduced by at least $25 \%$ the levels of TNF- $\alpha$ triggered by LPS stimulation.

\begin{tabular}{|c|c|c|}
\hline $\begin{array}{l}\text { Extracts } \\
\text { E. gracilis }\end{array}$ & $\begin{array}{c}\text { TNF- } \alpha \\
24 \mathrm{~h}\end{array}$ & $\begin{array}{l}\text { TNF- } \alpha \\
4 \text { days }\end{array}$ \\
\hline $\mathrm{FE}$ & 1 & 2 \\
\hline sFE1 & 0.1 & 0.1 \\
\hline sFE2 & 1 & 1 \\
\hline sFE3 & 10 & 10 \\
\hline sFE4 & 2 & 2 \\
\hline sFE5 & 5 & 5 \\
\hline sFE8 & 1 & 2 \\
\hline
\end{tabular}

Since E. gracilis might be proposed as a functional food for long-term consumption to prevent gut-derived systemic inflammation, in a parallel set of experiments, we investi- 
gated whether E. gracilis extracts maintain the anti-inflammatory activity at a longer time of exposure, with no significant alteration in the extent of the anti-inflammatory effect. Therefore, human primary macrophages were pretreated for 3 days with FE or sFE and finally challenged with LPS for $24 \mathrm{~h}$. In human macrophages pretreated with E. gracilis, LPS increased production of TNF- $\alpha(562.2 \pm 89.31 \mathrm{pg} / \mathrm{mL})$ at a similar extent observed in not pretreated cells (data not shown), ruling out the hypothesis of functional unresponsiveness or down stimulation caused in macrophages by continuous exposure to E. gracilis extracts. Moreover, long-term exposure to E. gracilis did not significantly alter the concentration of extracts able to reduce by $25 \%$ the production of LPS-induced TNF- $\alpha$ (Table 2, 4 days). No significant increase in TNF- $\alpha$ production was observed in human macrophages incubated for $24 \mathrm{~h}$ or 4 days with FE or sFE without LPS (data not shown).

\subsection{Extracts from E. gracilis Increase the Intracellular Reducing Potential}

Increased GSH levels ensure the antioxidant potential in cells, providing additional mechanisms for ROS scavengers. In our experiments, HT-29 cells were exposed to FE and sFE endowed with anti-inflammatory activity (Figure 4). Following 4 days of stimuli, cells reported increased intracellular GSH. In particular, FE, sFE2, sFE3, and sFE5 were the most effective in improving the reducing potential in the HT-29 cell line (Figure 5).

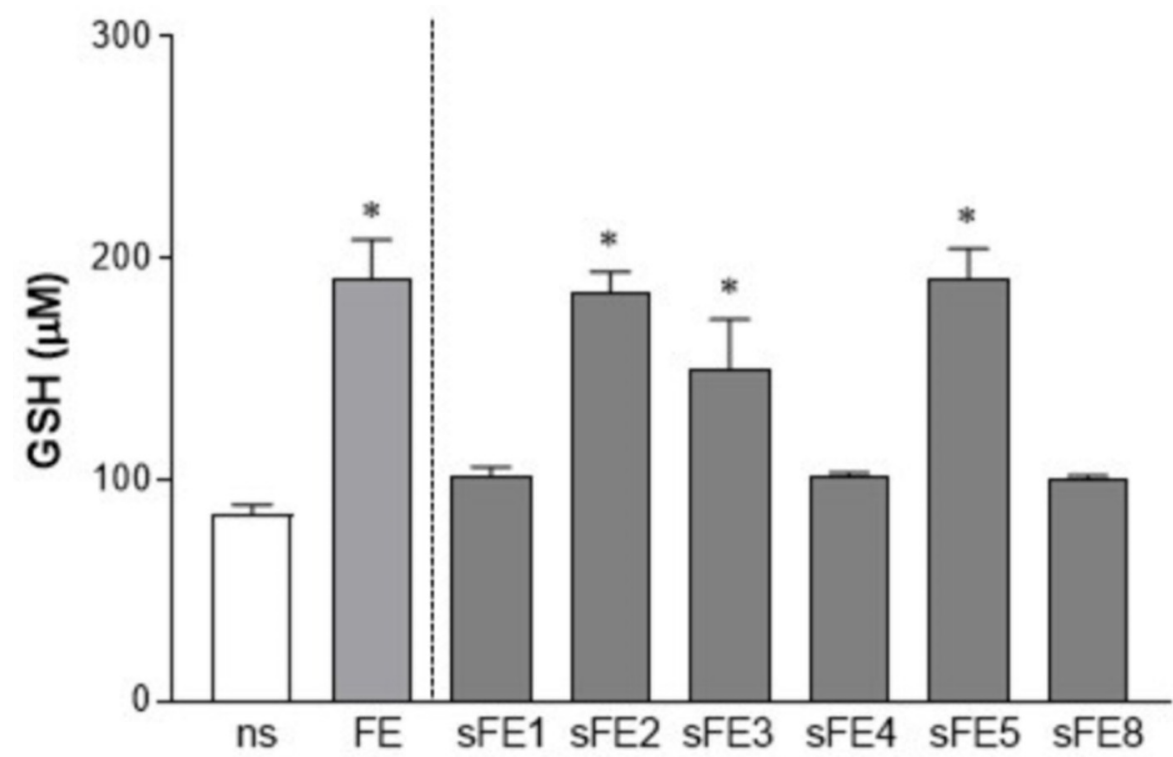

Figure 5. FE and sFE increase intracellular GSH levels. HT-29 were incubated with $10 \mu \mathrm{g} / \mathrm{mL}$ of extracts from E. gracilis for 4 days. Stimuli were renewed every day. Cells were then assessed for GSH content using Ellman's method. Absorbance was recorded at $412 \mathrm{~nm}$, and values were plotted on a standard curve obtained by serial dilution of $N$-acetylcysteine. Data are reported as mean $\pm \mathrm{SE}$ of data obtained from two independent experiments, each performed in triplicate. ${ }^{*}$ denotes $p<0.05$ vs. non-stimulated cells (ns).

\subsection{Extracts from E. gracilis Reduce Intracellular Reactive Oxygen Species Generated by LPS}

As reported in Figure 6, FE significantly reduced intracellular ROS in HT-29 cells stimulated with LPS. At the same, sFE2, sFE3, and sFE5, the sub-fractionated extracts reported to reduce TNF- $\alpha$ production (Figure 4), dampened the intracellular reactive oxygen burst generated by LPS (Figure 6B). In accordance with data on GSH intracellular content (Figure 5), sFE1, sFE4, and sFE8 did not report antioxidative capability in LPSstimulated cells (Figure 6A). Among the sFE, sFE3 significantly differed from FE $(p<0.05)$, suggesting that this extract's antioxidative capability was reduced compared with FE, even if still effective. Incubation of HT-29 cells with extracts alone $(10 \mu \mathrm{g} / \mathrm{mL})$ did not affect intracellular ROS generation (data not shown). 
A

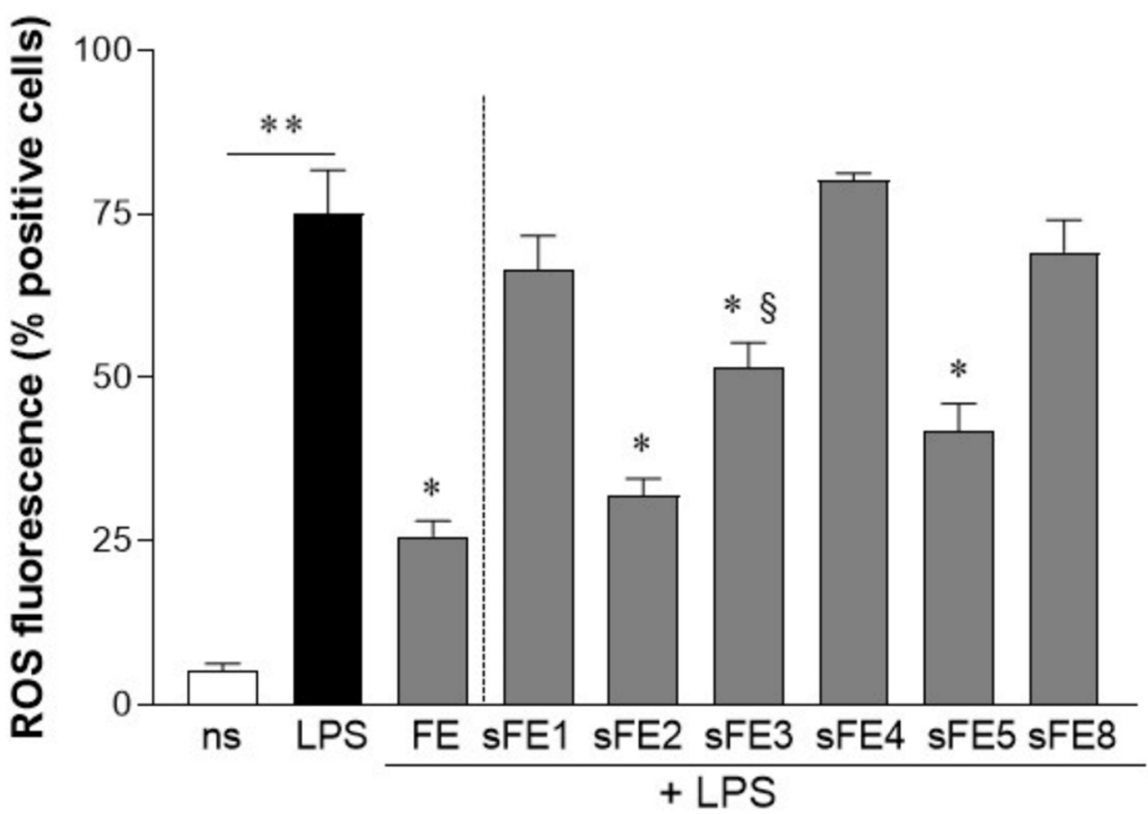

B
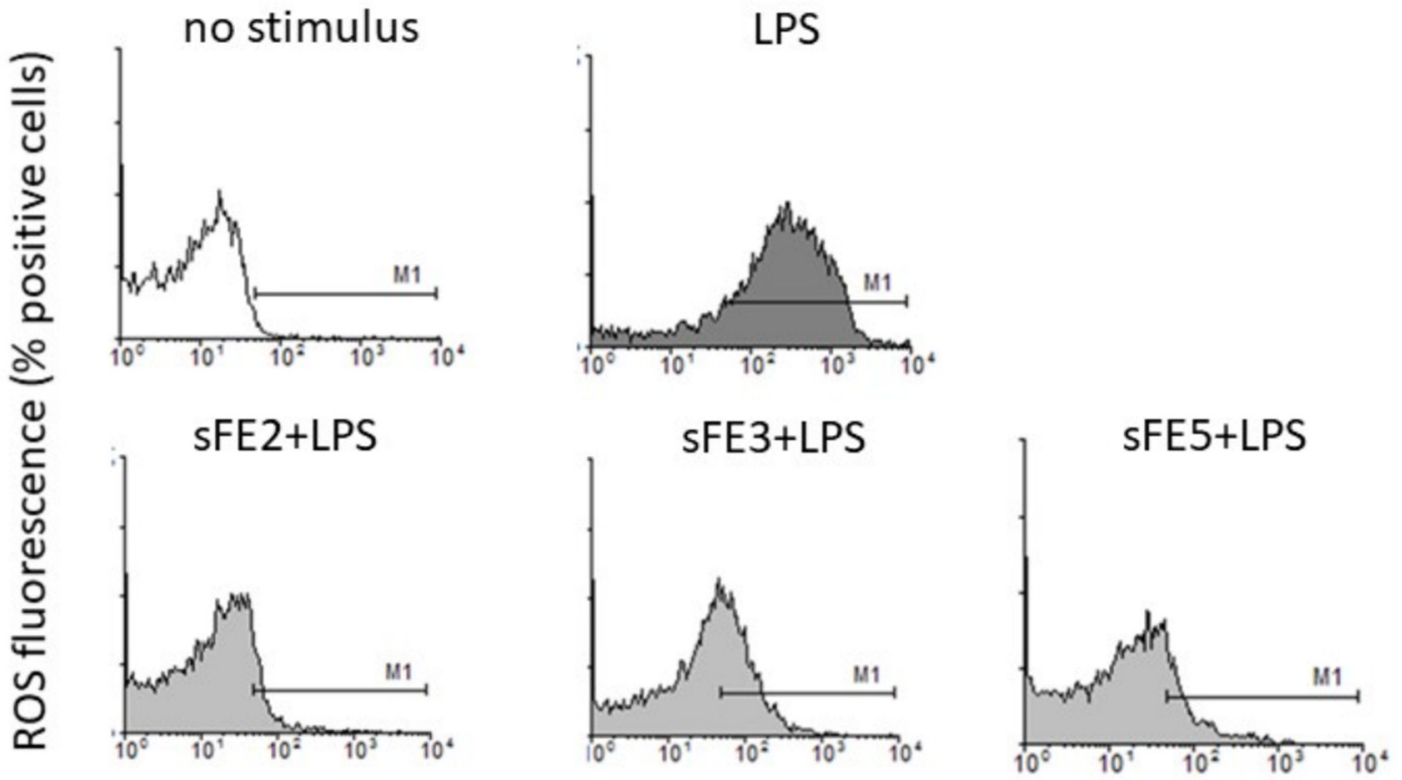

Figure 6. FE and sFE reduce intracellular reactive oxygen species generation. HT-29 cells were incubated with $10 \mu \mathrm{g} / \mathrm{mL}$ of FE or sFE for 3 days. Stimuli were renewed every day. Cells were then stimulated with LPS (100 ng/mL) for $24 \mathrm{~h}$ and then loaded with $10 \mu \mathrm{M} \mathrm{2}$ ', $7^{\prime}$-dichlorodihydrofluorescein diacetate $\left(\mathrm{H}_{2} \mathrm{DCFDA}\right)$, a fluorescent probe used to detect intracellular reactive oxygen species (ROS). Cells were analyzed by flow cytometry. For each experimental condition, $1 \times 10^{4}$ events were collected. (A) Percentage of $\mathrm{H}_{2}$ DCFDA-positive cells obtained from three independent experiments, each performed in duplicate. Data are reported as mean \pm SE. ${ }^{* *}$ denotes $p<0.05$ vs. non-stimulated cells. ${ }^{*}$ denotes $p<0.01$ vs. cells stimulated with LPS. $\S$ denotes $p<0.05$ vs. FE + LPS. (B) Representative histograms from cytofluorimetric analysis.

\subsection{Extracts from E. gracilis Prevent Lipid Peroxidation}

In addition to producing pro-inflammatory mediators, the generation of intracellular ROS is usually involved in the degradation of protein, oxidation of DNA, and lipid peroxidation, events frequently involved in the amplification of inflammation and the onset of chronic disorders [28]. Therefore, we evaluated the ability of FE and sFE to reduce 
ROS production (Figure 6) and prevent lipid peroxidation in LPS-activated HT-29 cells. TBA-reactive substances, a marker of lipid peroxidation, increased in HT-29 cells incubated with LPS (Figure 7). In contrast, lipid damage was blunted in cells pretreated for 3 days with $\mathrm{FE}$, sFE2, and sFE5, indicating a protective effect of specific extracts from E. gracilis in LPS-induced oxidative burst.

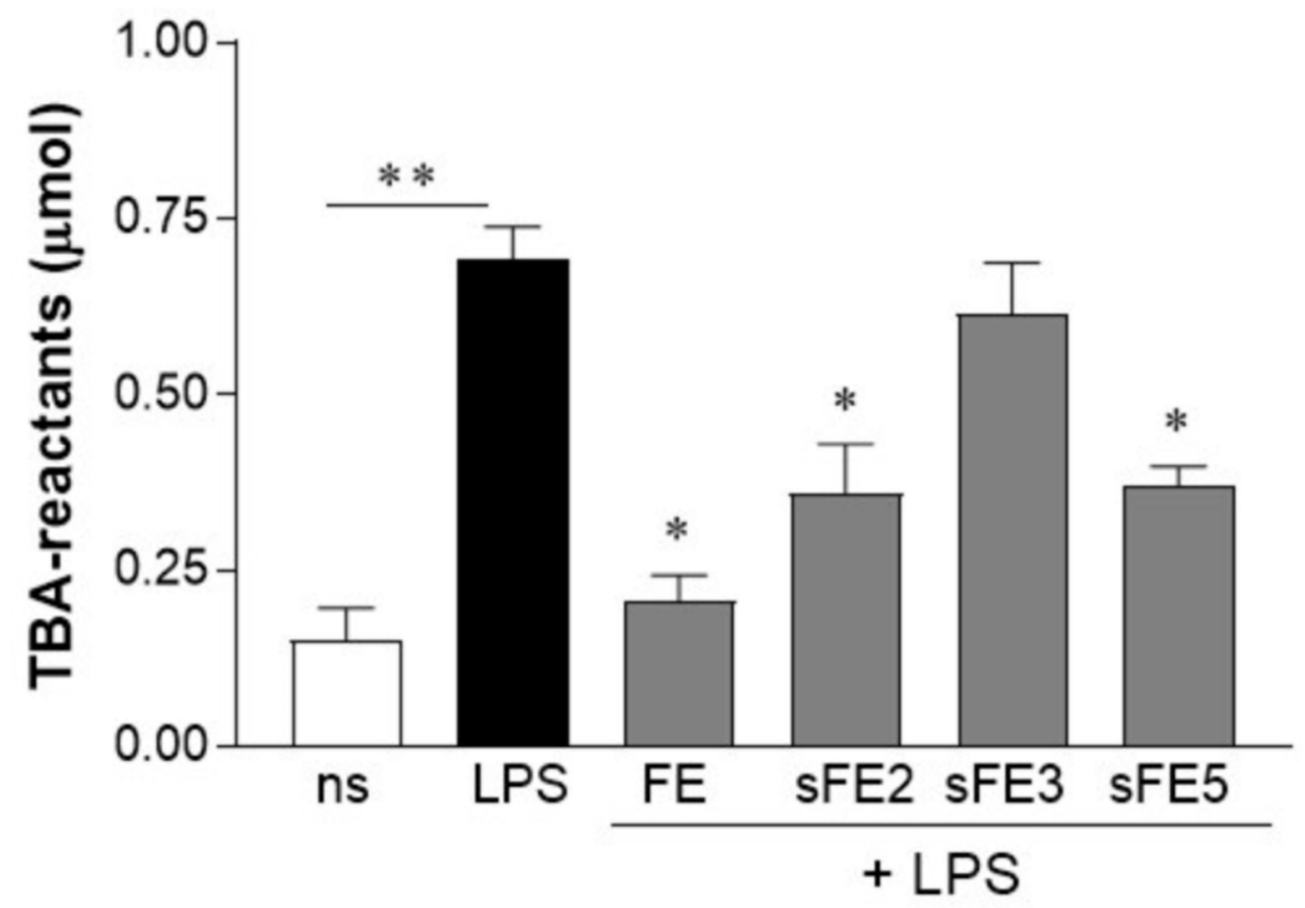

Figure 7. Pretreatment with FE and sFE prevents lipid peroxidation. HT-29 cells were incubated with $10 \mu \mathrm{g} / \mathrm{mL}$ of FE or sFE for 3 days. Stimuli were renewed every day. Cells were then stimulated with LPS (100 ng/mL) for $24 \mathrm{~h}$. Thiobarbituric acid (TBA)-reactants were evaluated in cell lysates and normalized to protein contents. Data are reported as mean $\pm \mathrm{SE}$ of results collected in three independent experiments, each performed in triplicate. ${ }^{* *}$ denotes $p<0.01$ vs. non-stimulated cells. * denotes $p<0.05$ vs. cells stimulated with LPS.

\section{Discussion}

Several experimental studies have so far evaluated the biological activity of E. gracilis, tested as a whole dried powder, with paramylon, water, ethanol, or dichloromethane extracts reporting antitumoral, anti-inflammatory, antioxidative, or proliferative effects $[11-13,15,17,18]$. However, fractions or whole preparations significantly differ in biological activities, as the composition of the extracts depends on the protocol used, the quality of the original material, and any prior treatment [8]. In this study, we investigated the activity of paramylon, acetone crude, and fractionated extracts from cultured cells of $E$. gracilis, a condition that led us to rule out any unnecessary pretreatment of the biological material. The anti-inflammatory and antioxidant activities on primary macrophages and intestinal epithelial cell line were determined for each fraction to identify extracts endowed with increased or reduced activities compared with the crude extract.

In our protocol, we used acetone as the solvent to obtain the crude extract. Indeed, we recently reported that acetone extract of Euglena is endowed with biological activity and modulated microglial activation by inhibiting the expression and release of pro-inflammatory molecules in LPS-induced neuroinflammation [38]. Moreover, acetone extracts photosynthetic pigments with a wide range of polarity and yields fractions enriched in carotenoids [39]. Finally, acetone precipitates paramylon [39], giving us the possibility to test the antioxidant and anti-inflammatory activities of $E$. gracilis in paramylon-free fractions [29-34]. 
Whereas paramylon has been indicated as the most important antioxidant fraction in E. gracilis, in this study we were unable to associate any anti-inflammatory and antioxidant activities with the paramylon fraction (Figure 2). In paramylon-free fractions, subsequent extractions led us to identify sFE1 as being most enriched in $\beta$-carotene. Carotene plays a variety of essential functions, and the multiple benefits of carotenoids for human health are supposedly linked to their antioxidant and anti-inflammatory effects [40]. The sFE1 fraction reported anti-inflammatory but not antioxidant activities (Figures 4 and 6), confirming a biological response to ROS-independent inflammatory stimuli [41,42]. Our study identified specific sFE from E. gracilis enriched in pheophytin a (sFE2), canthaxanthin (sFE5), and pheophorbides (sFE8) endowed with significant anti-inflammatory activity, as determined by the reduction in TNF- $\alpha$ production in LPS-activated human primary macrophages (Figure 4). Some of the sFE increased the reducing potential in cells, demonstrating antioxidative effects to counteract LPS-induced ROS levels and cell damage (Figures 5-7).

The subfractionation process of the FE into sFE2, sFE3, and sFE8 resulted in the breakdown of chlorophylls into pheophytins and pheophorbides. Interestingly, the digestion of chlorophylls in the human intestine yields pheophytin and pheophorbide too [43], suggesting the gut as the ideal bioreactor able to increase the biological effects of E. gracilis naturally. Pheophytins and pheophorbides are anti-inflammatory agents able to suppress inflammation via reducing nitric oxide production [44]. Here we report that pheophytins also quenched reactive oxygen species (Figure 6) and increased the reducing potential in cells (Figure 5). However, pheophytin a (sFE2) only prevents LPS-induced lipid peroxidation (Figure 7), revealing a more meaningful activity for pheophytin a or different stability [45]. The pheophorbides in sFE8 reported a substantial reduction in TNF- $\alpha$ production, with no antioxidative potential. Indeed, TNF- $\alpha$ is involved in cancer promotion and progression, and pheophorbides have shown important antitumor activities [43,46].

Our results integrate a growing body of knowledge about the use of E. gracilis as a functional food. The biotechnological applications of E. gracilis allow the production of different metabolites that, together with antioxidants, pigments, minerals, and vitamins, compose a mixture that has been poorly characterized for its chemical composition and biological effects. The assessment of the component-function relationship and mechanisms of action has therefore generated confounding results and controversies. Paramylon, the unique component of E. gracilis, is not an exception. Oral administration of this linear $\beta$ - $(1,3)$-glucan polymer has been reported to prevent acute hepatic injuries induced by $\mathrm{CCl}_{4}$ administration via antioxidative mechanisms and to inhibit atopic dermatitis in mice to a similar or greater extent than prednisolone $[11,18]$. In vitro experiments have reported that paramylon activates pro-inflammatory pathways and ROS production in neutrophils, monocytes, macrophages, and lymphocytes [15,47]. Moreover, several different compounds have been reported in extracts from Euglena, depending on the protocols and techniques $[48,49]$. The opposite results can be explained by different biological experimental models and different growing conditions and preparation protocols of algae sources, leading to variability in concentrations of molecules, degree of purity, or sample contaminations [37]. It has been proven that bacterial products usually contaminate cropderived nutrients, thus resulting in nonspecific immune effects in vitro [15,50]. For these reasons, the experiments described in this study were performed with extracts obtained from E. gracilis cultured under in vitro standardized growing conditions, and extracts were prepared in pyrogen-free solutions, thus ruling out any possible nonspecific activities in cultured cells.

Systemic endotoxemia is characterized by leakage of LPS from the intestinal lumen into the bloodstream [22]. Usually, intestinal dysbiosis and inflammation are responsible for the reduction in sealing properties of the intestinal wall, but circulating levels of LPS are unexpectedly detected even in healthy conditions [51,52]. More significant, transient increase in circulating bacterial LPS triggers systemic inflammation characterized by macrophage recruitment, pro-inflammatory cytokine production, and alterations of hepatic, adrenal, and cardiovascular functions [52]. During bacterial endotoxemia, a 
plethora of soluble factors and highly reactive species are produced-each one is characterized by pathological effects that are not correctly counteracted by the anti-inflammatory and scavenger cellular mechanisms, amplifying the tissue damage. TNF- $\alpha$ is one of the first pro-inflammatory mediators released by macrophages following stimulation with LPS. Immediately after secretion, TNF- $\alpha$ orchestrates the pro-inflammatory cascade and via paracrine and autocrine signaling it activates various cell populations to amplify the inflammatory response. Therapeutic blockade of TNF- $\alpha$ has been proposed in different inflammatory-related conditions, including rheumatoid arthritis and inflammatory bowel disease $[41,42]$. However, prolonged microbial stimulation and chronic immune suppression exhaust tissue macrophages and reprogram cytokine production [53]. Dietary consumption of nutrients endowed with immunomodulatory activities should be a timely way to prevent the occurrence of intestinal dysbiosis and systemic inflammation while preserving macrophage function and survival of epithelial cells. In this study, long-term (4 days) exposure to $E$. gracilis extracts (i) did not affect macrophages responsiveness to LPS, (ii) maintained the anti-inflammatory effects of extracts (Table 3), and (iii) supplied the epithelial cells with reducing potential (Figure 5). Previous studies reported production by Euglena of $\alpha$-tocopherol and glutathione able to change the redox status in cells. Moreover, culture conditions of microalgae such as carbon and nitrogen sources or tolerable stress induction can increase the yield of these biomolecules, further improving the nutritional importance of E. gracilis [37]. In morbid obesity, the increased supply of energy substrates and the inflammatory environment result in excessive mitochondrial ROS generation that finally contributes to the progression of obesity-related diseases such as atherosclerosis and type 2 diabetes. Conversely, low physiological levels of ROS, primarily generated at the plasma membrane and endomembrane, are required for normal cellular functioning and intracellular signaling [54]. Our study provides evidence that specific extract fractions of $E$. gracilis promote cellular reducing potential and avoid lipid peroxidation, conditions able to counteract LPS-induced oxidative burst (Figure 7). Moreover, our data reveal that different biological activities can be ascribed to various extracts of E. gracilis and that sub-fractionation can help target the anti-inflammatory and antioxidant effects. This study supports the role of E. gracilis supplementation in controlling intestinal bacteria-derived inflammatory conditions and the chronic disorders related to metabolic endotoxemia, but further studies are required for definitive conclusions.

Supplementary Materials: The following are available online at https:/ / www.mdpi.com/article/10 $.3390 /$ microorganisms9102058/s1, Figure S1: Chromatograms of subfractions sFE1 $\div$ sFE8 acquired at $438 \mathrm{~nm}$.

Author Contributions: Conceptualization, P.B., A.P. (Anna Piovan) and R.F.; methodology and investigation, P.B., A.P. (Anna Piovan), A.P. (Anthony Pauletto) and V.D.C.; writing—original draft preparation, P.B., A.P. (Anna Piovan) and R.F.; supervision, writing-review and editing, R.C.; funding acquisition, P.B. All authors have read and agreed to the published version of the manuscript.

Funding: This research received no external funding.

Institutional Review Board Statement: The study was conducted according to the guidelines of the Declaration of Helsinki, and approved by the Ethics Committee of the Padova University Hospital (registration number CE: 091/2016).

Informed Consent Statement: Informed consent was obtained from all subjects involved in the study.

Data Availability Statement: All data are available in the Manuscript.

Conflicts of Interest: The authors declare no conflict of interest.

\section{References}

1. Buetow, D.E. The Biology of Euglena; Academic Press: New York, NY, USA, 1989; Volume I-IV.

2. Enzing, A.C.; Ploeg, M.; Barbosa, M. Microalgae-based products for the food and feed sector: An outlook for Europe. JRC Sci. Policy Rep. 2014, 19-37. [CrossRef] 
3. Laza, M.E.P.; Errero, M.I.H.; Ifuentes, A.L.C. Innovative Natural Functional Ingredients from Microalgae. J. Agric. Food Chem. 2009, 57, 7159-7170. [CrossRef]

4. $\quad$ EFSA NDA Panel (EFSA Panel on Nutrition, Novel Foods and Food Allergens). Scientific Opinion on the safety of dried whole cell Euglena gracilis as a novel food pursuant to Regulation (EU) 2015/2283. EFSA J. 2020, 18, e06100. [CrossRef]

5. Zeng, M.; Hao, W.; Zou, Y.; Shi, M.; Jiang, Y.; Xiao, P.; Lei, A.; Hu, Z.; Zhang, W.; Zhao, L.; et al. Fatty acid and metabolomic profiling approaches differentiate heterotrophic and mixotrophic culture conditions in a microalgal food supplement 'Euglena'. BMC Biotechnol. 2016, 16, 49. [CrossRef] [PubMed]

6. Barsanti, L.; Passarelli, V.; Evangelista, V.; Frassanito, A.M.; Gualtieri, P. Chemistry, physico-chemistry and applications linked to biological activities of b-glucans. Nat. Prod. Rep. 2011, 28, 457-466. [CrossRef] [PubMed]

7. Rischer, H.; Wiebe, M.G.; Wang, Y.; Seppa, T. Euglena gracilis growth and cell composition under different temperature, light and trophic conditions. PLoS ONE 2018, 13, e0195329. [CrossRef]

8. Quesada, L.A.; Lustig, E.S.D.; Marechal, L.R.; Belocopitow, E. Antitumor activity of paramylon on sarcoma-180 in mice. Gan 1976, $67,455-459$.

9. Kondo, Y.; Kato, A.; Hojo, H.; Nozoe, S.; Takeuchi, M.; Ochi, K. Cytokine-related immunopotentiating activities of paramylon, a beta-(1->3)-D-glucan from Euglena gracilis. J. Pharm. Dyn. 1992, 15, 617-621. [CrossRef]

10. Koizumi, N.; Sakagami, H.; Utsumi, A.; Fujinaga, S.; Takeda, M.; Asano, K.; Sugawara, I.; Ichikawa, S.; Kondo, H.; Mori, S.; et al. Anti-HIV (human immunodeficiency virus) activity of sulfated paramylon. Antiv. Res. 1993, 21, 1-14. [CrossRef]

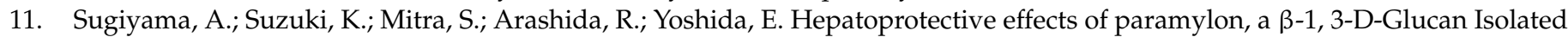
from Euglena gracilis Z, on Acute Liver Injury Induced by Carbon Tetrachloride in Rats. J. Vet. Med. Sci. 2009, 71, 885-890. [CrossRef]

12. Toliva, A.; Conforti, V.; Cordoba, O.; Flores, L. Chemical constituents and biological activity of Euglena gracilis extracts. J. Pharm. Res. 2013, 7, 209-214. [CrossRef]

13. Watanabe, T.; Shimada, R.; Matsuyama, A.; Yuasa, M. Antitumor activity of the $\beta$-glucan paramylon from Euglena against preneoplastic colonic aberrant crypt. Food Funct. 2013, 4, 1685-1690. [CrossRef]

14. Shimada, R.; Fujita, M.; Yuasa, M.; Sawamura, H.; Watanabe, T.; Nakashima, A.; Suzuki, K. Oral administration of green algae, Euglena gracilis, inhibits hyperglycemia in OLETF rats, a model of spontaneous type 2 diabetes. Food Funct. 2016, 7, 4655-4659. [CrossRef] [PubMed]

15. Russo, R.; Barsanti, L.; Evangelista, V.; Frassanito, A.M.; Longo, V.; Pucci, L.; Penno, G.; Gualtieri, P. Euglena gracilis paramylon activates human lymphocytes by upregulating pro- inflammatory factors. Food Sci. Nutr. 2016, 5, 205-214. [CrossRef] [PubMed]

16. Sugimoto, R.; Ishibashi-ohgo, N.; Atsuji, K.; Miwa, Y.; Iwata, O. Euglena extract suppresses adipocyte-differentiation in human adipose-derived stem cells. PLoS ONE 2018, 13, e0192404. [CrossRef] [PubMed]

17. Suzuki, K.; Nakashima, A.; Igarashi, M.; Saito, K.; Konno, M.; Yamazaki, N.; Takimoto, H. Euglena gracilis Z and its carbohydrate storage substance relieve arthritis symptoms by modulating Th17 immunity. PLoS ONE 2018, 13, e0191462. [CrossRef]

18. Sugiyama, A.; Hata, S.; Suzuki, K.; Yoshida, E.; Nakano, R. Oral administration of paramylon, a $\beta$-1,3-D-glucan isolated from Euglena gracilis Z inhibits development of atopic dermatitis-Like skin lesions in NC/Nga mice. J. Vet. Med. Sci. 2010, 72, 755-763. [CrossRef]

19. Stienstra, R.; Duval, C.; Michael, M.; Kersten, S. PPARs, Obesity, and Inflammation. PPAR Res. 2007, 2007, 095974. [CrossRef]

20. World Health Organization. Obesity and Overweight. 2018. Available online: https://www.who.int/news-room/fact-sheets/ detail/obesity-and-overweight (accessed on 16 August 2021).

21. Olefsky, J.M.; Glass, C.K. Macrophages, Inflammation, and Insulin Resistance. Annu. Rev. Physiol. 2010, 72, 219-246. [CrossRef]

22. Brun, P.; Castagliuolo, I.; Leo, V.D.; Buda, A.; Pinzani, M.; Palu, G.; Martines, D. Increased intestinal permeability in obese mice: New evidence in the pathogenesis of nonalcoholic steatohepatitis. Am. J. Physiol. Grastrointest. Liver Physiol. 2007, 292, G518-G525. [CrossRef] [PubMed]

23. Cani, P.D.; Amar, J.; Iglesias, M.A.; Poggi, M.; Knauf, C.; Bastelica, D.; Neyrinck, A.M.; Fava, F.; Tuohy, K.M.; Chabo, C.; et al. Metabolic endotoxemia initiates obesity and insulin resistance. Diabetes 2007, 56, 1761-1772. [CrossRef] [PubMed]

24. Vergès, B.; Duvillard, L.; Lagrost, L.; Vachoux, C.; Garret, C.; Bouyer, K.; Courtney, M.; Pomié, C.; Burcelin, R. Changes in lipoprotein kinetics associated with type 2 diabetes affect the distribution of lipopolysaccharides among lipoproteins. J. Clin. Endocrinol. Metab. 2014, 99, E1245-E1253. [CrossRef] [PubMed]

25. Dludla, P.V.; Nkambule, B.B.; Jack, B.; Mkandla, Z.; Mutize, T.; Silvestri, S.; Orlando, P.; Tiano, L.; Louw, J.; Mazibuko-Mbeje, S.E. Inflammation and oxidative stress in an obese state and the protective effects of gallic acid. Nutrients 2019, 11, 23. [CrossRef]

26. Loh, K.; Deng, H.; Fukushima, A.; Cai, X.; Boivin, B.; Galic, S.; Bruce, C.; Shields, B.J.; Skiba, B.; Ooms, L.M.; et al. Reactive Oxygen Species Enhance Insulin Sensitivity. Cell Metab. 2009, 10, 260-272. [CrossRef] [PubMed]

27. Cramer, M.; Myers, J. Growth and Photosynthetic Characteristics of Euglena graeilis. Arch. Mikrobiol. 1952, 17, 384-402. [CrossRef]

28. Schwartzbach, S.D.; Shigeoka, S. Euglena: Biochemistry, Cell and Molecular Biology; Springer International Publishing: New York, NY, USA, 2017.

29. Lichtenthaler, H.K. Chlorophylls and carotenoids: Pigments of photosynthetic biomembranes. Method Enzymol. 1987, 148, 350-382.

30. Yang, C.M.; Chang, K.W.; Yin, M.H.; Huang, H.M. Methods for the determination of the chlorophylls and their derivatives. Taiwania 1998, 43, 116-122. 
31. Hager, A.; Stransky, H. Das carotinoidmuster und die verbreitung des lichtinduzierten xanthophyllcyclus in verschiedenen algenklassen. V. Ein- zelne vertreter der Cryptophyceae, Euglenophyceae, Bacillariophyceae, Chrysophyceae und Phaeophyceae. Arch. Mikrobiol. 1970, 73, 77-89. [CrossRef]

32. Heelis, D.V.; William Kernick, W.; Phillips, G.O.; Davies, K. Separation and identification of the carotenoid pigments of stigmata isolated from light-grown cells of Euglena gracilis strain Z. Arch. Microbiol. 1979, 121, 207-211. [CrossRef]

33. Hynstovaa, V.; Sterbovaa, D.; Klejdusa, B.; Hedbavnya, J.; Huskaa, D.; Adam, V. Separation, identification and quantification of carotenoids and chlorophylls in dietary supplements containing Chlorella vulgaris and Spirulina platensis using High Performance Thin Layer Chromatography. J. Pharm. Biomed. Analysis 2018, 148, 108-118. [CrossRef]

34. Krinski, N.I.; Gordon, A.; Stern, A.I. The appearance of neoxanthin during the regreening of dark-grown Euglena. Plant Physiol. 1964, 39, 441-445. [CrossRef]

35. Rahman, I.; Kode, A.; Biswas, S.K. Assay for quantitative determination of glutathione and glutathione disulfide levels using enzymatic recycling method. Nat. Protoc. 2007, 1, 3159-3165. [CrossRef]

36. Brun, P.; Pathak, S.; Castagliuolo, I.; Palù, G.; Brun, P.; Zuin, M.; Cavazzana, R.; Martines, E. Helium generated cold plasma finely regulates activation of human fibroblast-like primary cells. PLoS ONE 2014, 9, e104397. [CrossRef]

37. Rodríguez-Zavala, J.S.; Ortiz-Cruz, M.A.; Mendoza-Hernández, G.; Moreno-Sánchez, R. Increased synthesis of $\alpha$-tocopherol, paramylon and tyrosine by Euglena gracilis under conditions of high biomass production. J. Appl. Microbiol. 2010, 109, $2160-2172$. [CrossRef] [PubMed]

38. Piovan, A.; Filippini, R.; Corbioli, G.; Dalla Costa, V.; Giunco, E.M.V.; Burbello, G.; Pagetta, A.; Gisti, P.; Zusso, M. Carotenoid Extract Derived from Euglena gracilis Overcomes Lipopolysaccharide-Induced Neuroinflammation in Microglia: Role of NF- $\mathrm{B}$ and Nrf2 Signaling Pathways. Mol. Neurobiol. 2021, 58, 3515-3528. [CrossRef] [PubMed]

39. Pasquet, V.; Chérouvrier, J.R.; Farhat, F.; Thiéry, V.; Piot, J.M.; Bérard, J.B.; Kaas, R.; Serive, B.; Patrice, T.; Cadoret, J.P.; et al. Study on the microalgal pigments extraction process: Performance of microwave assisted extraction. Process. Biochem. 2011, 46, 59-67. [CrossRef]

40. Amaro, H.M.; Fernandes, F.; Valentão, P.; Andrade, P.B.; Sousa-Pinto, I.; Malcata, F.X.; Guedes, A.C. Effect of solvent system on extractability of lipidic components of Scenedesmus obliquus (M2-1) and Gloeothece sp. on antioxidant scavenging capacity thereof. Mar. Drugs 2015, 13, 6453-6471. [CrossRef]

41. Nair, S.; Arora, S.; Lim, J.Y.; Lee, L.H.; Lim, L.H.K. The regulation of TNF $\alpha$ production after heat and endotoxin stimulation is dependent on Annexin-A1 and HSP70. Cell Stress Chaperones 2015, 20, 583-593. [CrossRef] [PubMed]

42. Parameswaran, N.; Patial, S. Tumor Necrosis Factor- $\alpha$ Signaling in Macrophages. Crit. Rev. Eukaryot. Gene Expr. 2010, 20 , 87-103. [CrossRef]

43. Saide, A.; Lauritano, C.; Ianora, A. Pheophorbide A: State of the art. Mar. Drugs 2020, 18, 257. [CrossRef]

44. Islam, M.N.; Ishita, I.J.; Jin, S.E.; Choi, R.J.; Lee, C.M.; Kim, Y.S.; Jung, H.A.; Choi, J.S. Anti-inflammatory activity of edible brown alga Saccharina japonica and its constituents pheophorbide a and pheophytin a in LPS-stimulated RAW 264.7 macrophage cells. Food Chem. Toxicol. 2013, 55, 541-548. [CrossRef] [PubMed]

45. Ditmars, W.E.; Van Winkle, Q. A comparative study of pheophytin a and pheophytin b monolayers. J. Phys. Chem. 1968, 72, 39-45. [CrossRef]

46. Balkwill, F. TNF- $\alpha$ in promotion and progression of cancer. Cancer Metastasis Rev. 2006, 25, 409-416. [CrossRef] [PubMed]

47. Kankkunen, P.; Teirilä, L.; Rintahaka, J.; Alenius, H.; Wolff, H.; Matikainen, S. (1,3)- $\beta$-Glucans Activate Both Dectin-1 and NLRP3 Inflammasome in Human Macrophages. J. Immunol. 2010, 84, 6335-6342. [CrossRef]

48. Matsuda, F.; Hayashi, M.; Kondo, A. Comparative profiling analysis of central matabolites in Euglena gracilis under variuos cultivation conditions. Biosci. Biotechnol. Biochem. 2011, 75, 2253-2256. [CrossRef]

49. Santiago-Vázquez, L.Z.; Mydlarz, L.D.; Pavlovich, J.G.; Jacobs, R.S. Identification of hydroxy fatty acids by liquid chromatographyatmospheric pressure chemical ionization mass spectroscopy in Euglena gracilis. J. Chromatogr. B 2004, 803, 233-236. [CrossRef]

50. Khalid, S.; Shahid, M.; Tahir, N.; Bibi, I.; Sarwar, T.; Shah, A.H.; Niazi, N.K. A review of environmental contamination and health risk assessment of wastewater use for crop irrigation with a focus on low and high-income countries. Int. J. Environ. Res. Public Health 2018, 15, 895. [CrossRef]

51. Bala, S.; Marcos, M.; Gattu, A.; Catalano, D.; Szabo, G. Acute binge drinking increases serum endotoxin and bacterial DNA levels in healthy individuals. PLoS ONE 2014, 9, e96864. [CrossRef] [PubMed]

52. Ahola, A.J.; Lassenius, M.I.; Forsblom, C.; Harjutsalo, V.; Lehto, M.; Groop, P.H. Dietary patterns reflecting healthy food choices are associated with lower serum LPS activity. Sci. Rep. 2017, 7, 6511. [CrossRef] [PubMed]

53. Shnyra, A.; Brewington, R.; Alipio, A.; Amura, C.; Morrison, D.C. Reprogramming of Lipopolysaccharide-Primed Macrophages Is Controlled by a Counterbalanced Production of IL-10 and IL-12. J. Immunol. 1998, 160, 3729-3736. Available online: http: //www.jimmunol.org/content/160/8/3729 (accessed on 16 August 2021).

54. Veal, E.A.; Day, A.M.; Morgan, B.A. Hydrogen Peroxide Sensing and Signaling. Mol. Cell 2007, 26, 1-14. [CrossRef] [PubMed] 